\title{
Estudo Analítico, Projeto e Construção de um Pêndulo Duplo Didático.
}

\author{
Arthur Rosse da Silva (IC), Katia Lucchesi Cavalca (PQ).
}

\section{Resumo}

Este projeto segue em continuidade ao desenvolvimento do estudo analítico e simulação numérica do comportamento de um pêndulo duplo de acordo com as condições iniciais impostas ao sistema, conforme fora iniciado em agosto de 2013. Tendo em mãos os resultados do estudo precedente, pode-se avaliar e determinar parâmetros essências para o projeto detalhado de um pêndulo duplo didático. $O$ atual trabalho prevê a concepção do projeto de fabricação deste dispositivo e pode ser dividido em duas partes principais: dimensionamento dos elementos do mecanismo e integração do programa de análise dinâmica do pêndulo com o software CAD, para animação gráfica dos resultados, possibilitando melhor relação entre o fenômeno físico e a modelagem matemática numa demonstração em sala de aula.

Palavras Chave: pêndulo duplo, elementos de máquinas, simulação computacional.

\section{Introdução}

O pêndulo duplo consiste em um sistema composto por duas massas interligadas por hastes rígidas. $O$ domínio dos fenômenos relacionados ao seu comportamento dinâmico é de extrema importância no estudo dos movimentos rotacionais e oscilatórios na área de projetos mecânicos.

De tal modo, o objetivo principal deste trabalho é a realização do projeto detalhado de um dispositivo duplo pendular e sua construção para aplicações didáticas e experimentais dentro do ambiente acadêmico. Assim, tal estudo segue não apenas no sentido de validar a modelagem realizada anteriormente, mas também para consolidar metodologias importantes para 0 projeto de máquinas e dispositivos mecânicos.

\section{Resultados e Discussão}

Tendo como premissa os resultados provenientes das simulações dinâmicas realizadas no trabalho anterior, puderam-se definir os parâmetros críticos para dimensionamento e projeto de construção do pêndulo duplo didático ${ }^{1}$.

Ao longo do trabalho, diversas metodologias relacionadas ao projeto e desenvolvimento de máquinas foram empregadas, as quais englobam desde utilização de ferramentas de criatividade até a análise dos fatores de segurança dos elementos para vida sob fadiga ${ }^{2}$.

Os resultados obtidos para a determinação das forças resultantes nos principais componentes e 0 dimensionamento das peças do mecanismo foram satisfatórios para viabilizar a construção do duplo pêndulo, apresentando um projeto robusto e ao mesmo tempo compacto, uma vez que sua aplicação envolve o transporte do dispositivo para salas de aula e laboratórios dentro da universidade.

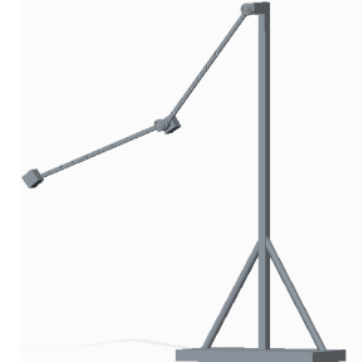

Figura 1. Modelo do pêndulo duplo didático.

$$
\text { Conclusões }
$$

A abordagem de pesquisa adotada contempla desde o estudo analítico das equações que regem o movimento do pêndulo duplo até o projeto e concepção deste dispositivo para a validação das teorias utilizadas.

Os resultados obtidos por meio das simulações computacionais e pelo dimensionamento inicial do pêndulo duplo foram de essencial importância para o projeto, principalmente nos quesitos que regem a determinação dos esforços atuantes nos componentes do dispositivo, a seleção dos materiais e a determinação dos fatores de segurança das principais peças.

Tal fato, atrelado às metodologias de projeto de máquinas, resultou num trabalho robusto e que atende aos objetivos de sua criação.

\section{Agradecimentos}

Agradeço à Prof. ${ }^{a}$ Katia Lucchesi pela oportunidade e orientação.

$\mathrm{E}$ aos meus pais por todo o apoio e incentivo.

1 Santos, Ilmar Ferreira, Dinâmica de Sistemas Mecânicos: Modelagem - Simulação -Visualização - Verificação, São Paulo, Editora Makron Books, 2001.

2 Norton, Robert L., Projeto de Máquinas - Uma Abordagem Integrada, $4^{\mathrm{a}}$ edição,Editora Bookman, 2013. 